\title{
京都鴨川の景観と春から秋の季節変化の魅カについて
}

\section{A Study on the Attraction of a Kyoto Kamo River Landscape Scene and the Season Change by Autumn from Spring}

\author{
福井 亘 ${ }^{*}$ 佐竹 悠理** 濱田 梓* 正嶋 大作* 瀨古 祥子* 高林 裕 ${ }^{*}$ \\ Wataru FUKUI Yuri SATAKE Azusa HAMADA Daisaku HIKISHIMA Sachiko SEKO Yutaka TAKABAYASHI
}

\begin{abstract}
This study was intended to clarify the change of charm and the impression of the season in river landscape and green open space. This study area was Kamo River by autumn from spring in Kyoto. There was direct interview question investigation from visitors on the both sides of the two sections. This investigation was the impression evaluation experiment using the SD method to investigate the impression of the river landscape scene every seasons. There analyzed factor analysis and profile analysis. Thera performed an analysis of variance between seasons (spring, summer and autumn) to check whether the impression evaluation in two sections included significant difference. The answer that there was the most accounted for $19.5 \%$ of the whole by a landscape scene. The people more than $90 \%$ of the respondent answered that the making of space feeling the four seasons was important. From the result of the SD method, it was easy to feel the change of the tree visually in autumn with spring, and it was thought that a natural element influenced an impression. In addition, an overall element including the urb an river and the townscape influenced an impression in the summer because the colors of the tree were monotonous.
\end{abstract}

Keywords: season change, river landscape scene, impression evaluation, direct questionnaire, factor analysis, Kamo River キーワード：季節変化，河川景観，印象評価，直接アンケート，因子分析法，鴨川

\section{1. はじめに}

水辺と緑地を併せ持つ河川空間は，都市において人々が㕷う親 水空間として重要な場といえる。1970年に親水機能の概念が提起 され, 1974 年に東京都江戸川区の古河親水公園が全国初の親水公 園として整備された。親水機能は治水, 利水と共に河川の備える べき三大機能としてその考え方は普遍化されてきている ${ }^{1}$ 。近年, 「美しい国づくり政策大綱」2）をはじめ，「景観緑三法」3) が制定 され，河川空間は都市の貴重なオープンスペースとして位置づけ られている。

そのような都市河川の中の魅力の一つに季節変化があり，季節 の魅力を活用した商品や観光 PR は身近なものとなっている。景 観は, 季節により変化し, 訪れる人々の要望も変化すると考えら れ，例えば，植物の開花や新緑，紅葉などの季節変化を取り込ん だ修景は，景観的に効果がある ${ }^{4)}$ 。観光庁は，「観光立国実現に向 けたアクション・プログラム 2015」を策定し，「色とりどりの魅 力を持つ日本」の発信と地方への誘客として, 四季折々の魅力を PR し，年間を通して訪日需要を創出する5）としている。

自治体による都市河川に関する取組みとしての一例として京都 市をみると「水辺の回廊整備・鴨川創造プラン」の実施や，「千年 の都・鴨川清流プラン」の策定など, 安全で, 美しく, 親しまれ る河川としての鴨川の整備が進められてきた ${ }^{6}$ 。また京都府では, 河川愛護意識の醸成から鴨川の魅力の全国への発信として，季節 ごとに「鴨川四季の日」を設けている7〕。ういった方向性から， 都市河川の親水空間としての整備や季節変化を取り入れた修景は, 今後も推進されるべき対象であると考えられよう。

これまで水辺景観に関わる研究において，空間の印象評価やイ メージに関する研究については, 長 ${ }^{8)}$ の河川空間構成が人に与え る印象について, 松永ら ${ }^{9)}$ の都市河川沿いの歩行空間に着目した 地域コミュニティへの影響や景観的役割，江頭ら 10）の河川景観 における心理評価と実態把握, 武藤ら 11) による CG を対象とし た主観評価などが報告されている。これらの既往研究では，スラ
イドなどによる静止画を利用し，評価アンケートを行っている。 また，河川環境整備に関する既往研究では，杉ら 12) の都市内を 流れる狭小河川に着目した河川整備方法, 増田ら 13) の周辺の土 地利用特性や景観に調和した都市河川の空間整備の方向性，渡辺 ら 14) の，樹林化に伴う河川景観変化などの報告がある。これら は，行政機関や住民に対するアンケートによる整備手法や土地の 構造，形状，構成素材，樹林などと景観との関係をみている。

季節変化に関わる既往研究では, 中村ら 15) が河川景観らしさ を設計に取り込むといった点に着目しており, 浅川ら 16) は緑地 におけるイメージへの季節変化の影響を検討，村上ら 17) は地域 景観の評価構造における季節変化を検討している。しかしながら， 季節を順に追った調查事例はほとんどみられない。また，調査方 法は室内でのスライド実験が主であり, 現地での直接アンケート による景観評価調査事例としては, 福井ら 18) の京都白川におけ る河川景観要素の好ましさに関する研究等があるものの，季節に 着目し,現地にて評価実験を行うこと自体, 調査の実例が少ない。

そこで本研究では，再整備が進められている京都市を流れる鴨 川において，来訪者を対象とした現地でのアンケート調査を通し て，水辺と緑地空間の春から秋の季節にかけての景観の魅力や印 象の変化を明らかにすることを目的とした。

なお，本調査では人々が憩う親水空間に着目している点，落葉 樹をはじめとした緑の変化が印象的な期間に着目している点から, 来訪者の多い 19，20）春，夏，秋の季節ごとに現地調査を行った。

\section{2. 調査方法}

\section{（1）調査対象河川之調査区間設定}

調査対象の都市河川は京都市中心部を流れる鴨川とし，北山大 橋～北大路橋（以下，北山・北大路区間） と三条大橋～四条大橋 (以下，三条・四条区間）の 2 区間を対象区間とした（図一-1)。 北山・北大路区間は京都府立植物園に隣接し, 周辺は住居専用地 域であり，三条・四条区間は先斗町の京町家が連なり，周辺は商

*京都府立大学大学院生命環境科学研究科 **名古屋市役所 


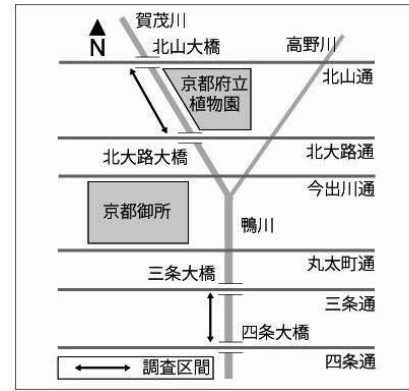

図-1 調査位置図

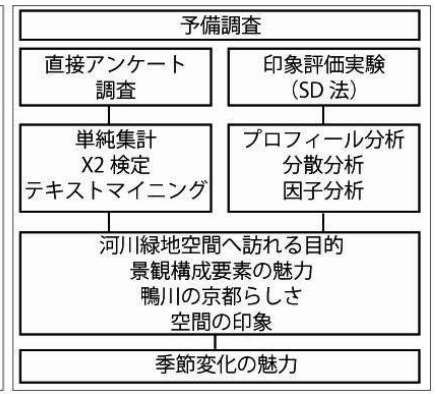

図-2 調査フロ一図
業地域となっている。北山・北大路区間の左岸には半木の道の桜, 右岸には賀茂街道沿いの二レ科植物の並木があり，春には鴨川茶 店などが催され，三条・四条区間の左岸には春の桜や秋の紅葉が 花の回廊として植栽されており，夏には右岸に鴨川納涼床が設置 され，これらは鴨川四季の日を紹介寸る京都府の広報でも取り上 げられている。

調査区間の設定については，前述の用途地域の違いに加えて， 既往研究を参考にした。北山大橋〜北大路橋では，御園橋〜三条 大橋までの中で，最も魅力的である ${ }^{21)}$ と示され，次いで三条・ 四条区間は，鴨川における商業地域で利用者が最も多い区間 6) と 報告されている。さらに，この 2 区間に共通していることは，季 節を感じる空間として京都府 ${ }^{22}$ ) が力を入れており，実際に多く の人が訪れているエリアでもあるという点である。これらのこと から, 季節を感じる空間づくりが進められ, 用途地域の違うこの エリアで調査することは，各季節における魅力を明らかにできる ものと考えられ，調査区間として設定した。

\section{(2) 予備調査}

調査フローは図一 2 に示した。2014 年 12 月 5 日に河川景観を 構成する要素である川, 植物, 生物, 遠景における魅力を抽出す るための予備調査を緑化系ワークショップ 23) 後に行った。学生 と一般事業者, 教員の計 25 人に北大路大橋から北山大橋を超え, 御園橋までの区間を歩いた後，アンケート用紙を配布し，各要素 について一年を通してイメージされるものを自由記述で回答して もらつた。その結果を基に本調査に向けた質問紙の作成を行った。

\section{(3) アンケート調査}

河川景観に対する認識調査は，予備調査を基にしたアンケート 調査用紙を用い，両区間の両岸の河川敷にて来訪者への直接イン タビュー形式で行った。表一1にアンケートの調査概要を示した。 なお, 調査対象者の抽出方法は, 来訪者全てに対しては不可能で あるが，可能な限り声をかけ，調査の協力を依頼した。調査に際 しては，1 日あたり約 6 名の調査員が同時にそれぞれの来訪者一 個別に対応した。

属性に関しては「性別」と「年齢」「住所」, 利用実態に関して は「来訪目的」と「来訪頻度」の質問項目を設けた。

景観と季節変化の魅力に対する認識に関しては，まず，区間や 対象要素を限定せず, 鴨川全体の魅力要素を把握するため,「鴨川 の観光資源 ${ }^{24)}$ 」して想起される要素を自由回答してもらった。 次に,「鴨川で季節変化を感じられると思いますか」という質問を 設け，「とても思う」から「全く思わない」までの 5 段階尺度で 評価してもらった。また，区間ごとに「今の季節 (調査時) にお ける鴨川の魅力」を予備調査で抽出した川, 植物, 生物, 遠景の それぞれの要素について回答（複数回答可）してもらつた。つづ けて，「季節を感じる空間づくりは重要だと思いますか小という質 問を設け，重要と回答した人についてはどのような点で重要なの か, その理由を自由回答で尋ねた。加えて，景観の魅力として地 域性に着目し，「この季節の鴨川は京都らしさを感じますかりとい
表一 1 アンケート概要

\begin{tabular}{|c|c|}
\hline 項目 & 調査概要 \\
\hline 調査対象区間と & 鴨川河川敷の2区間 総数 630 人 \\
\hline アンケート数 & 北山大橋から北大路大橋（春 112 人，夏 103 人，秋 102 人） \\
\hline & 三条大橋加四大橋区間（春 104 人，夏 101 人，秋 104 人） \\
\hline 調査方法 & アンケート調査・直接インタビュ一形式 \\
\hline 調査日程 & $\begin{array}{l}\text { 春 : } 2015 \text { 年 } 3 \text { 月 } 31 \text { 日 } 4 \text { 月 } 12 \text { 日, 夏 : 同年 } 8 \text { 月 } 12 \text { 日 9 月 } 11 \text { 日 } \\
\text { 秋 : 同年 } 11 \text { 月 } 6 \text { 日 } 11 \text { 月 } 27 \text { 日 }\end{array}$ \\
\hline 調査時間帯 & 6 時〜18 時の間, 日の出を目安に日の入迄。天候は雨を除く \\
\hline
\end{tabular}

\section{表—2 予備調査上位 10 位までの要素結果}

\begin{tabular}{|c|c|c|c|}
\hline 川 & 植物 & 生物 & 遠景 \\
\hline 水面の様子 (22) /水の紅葉 (21) /草花 (16)鳥 (45) /虫 (13) / 山 (25) / 建物 街並み
\end{tabular}
音 (17) /令才さ, 涼し/桜 色 (緑) (15) 人々の行動 (12)/ (17) /雲 (形) (14) さ (12)/水鳥, 飛し砛そよく葉音, 枝張り, 落魚 (10) /鳴き声 (5) / 送り火 (10)/山の紅 (7) /流れ (5) /開放葉 蕾, 新芽 (3)/芝/ペットの犬 ヌート1)葉 (8)/

感 落差工 中州, 子供生、高木 木のシルエッア (4) 猫 (3)/サン橋 納涼床 直線的な䀧 (3) / 以下10要素
$\begin{aligned} & \text { 要素り (2) / 以下10 } \\ & \text { 素 } \\ & \text { (1) }\end{aligned}$

※ (数字) は \%, $\mathrm{n}=17$

表一3 属性亡来訪目的 - 頻度（\%)

\begin{tabular}{|c|c|c|c|c|c|c|c|c|c|c|c|c|c|}
\hline \multirow{2}{*}{\multicolumn{14}{|c|}{\begin{tabular}{l|l|l|l|l|l|l|l} 
１0代 & 20 代 & 30 代 & 40 代 & 50 代 & 60 代 & 70 代 & 80 代〜
\end{tabular}}} \\
\hline & 女性 & 男性 & \multirow{2}{*}{\multicolumn{2}{|c|}{\begin{tabular}{|c|}
10 代 \\
27
\end{tabular}}} & 20 代 & 301 & 40 代 & & 50 代 & 60 代 & 70 代 & \multicolumn{2}{|c|}{80 代 } \\
\hline 北山春 & 65.2 & 34.8 & & & 15.2 & 11.6 & \multicolumn{2}{|c|}{9.8} & 17.0 & 24.1 & 16.1 & \multicolumn{2}{|r|}{3.6} \\
\hline 北山夏 & 33.0 & 67.0 & \multicolumn{2}{|c|}{0.0} & 1.9 & 1.0 & \multicolumn{2}{|c|}{7.8} & 16.5 & 32.0 & 31.1 & \multicolumn{2}{|r|}{9.7} \\
\hline 北山秋 & 52.5 & 47.5 & \multicolumn{2}{|c|}{4.0} & 9.9 & 3.0 & \multicolumn{2}{|c|}{2.0} & 5.0 & 30.7 & 34.7 & \multicolumn{2}{|r|}{10.9} \\
\hline 三条春 & 69.2 & 30.8 & \multicolumn{2}{|c|}{14.4} & 14.4 & 7.7 & \multicolumn{2}{|c|}{11.5} & 14.4 & 26.0 & 9.6 & \multicolumn{2}{|r|}{1.9} \\
\hline 三条夏 & 48.5 & 51.5 & \multicolumn{2}{|c|}{6.9} & 32.7 & 17.8 & \multicolumn{2}{|c|}{5.9} & 16.8 & 10.9 & 7.9 & \multicolumn{2}{|r|}{1.0} \\
\hline 三条秋 & 58.7 & 41.3 & \multicolumn{2}{|c|}{3.8} & 16.3 & 7.7 & \multicolumn{2}{|c|}{11.5} & 15.4 & 20.2 & 25.0 & \multicolumn{2}{|r|}{0.0} \\
\hline 住所 & 左京 & 右京 & 北 & 中京 & 上京 & 下京 & 西京 & 山科 & 東山 & 南 & 伏見 & 府内 & 府外 \\
\hline 北山春 & 9.8 & 3.6 & 38.4 & 2.7 & 1.8 & 2.7 & 0.0 & 0.9 & 0.9 & 1.8 & 0.9 & 4.5 & 32.1 \\
\hline 北山夏 & 15.5 & 1.0 & 71.8 & 1.0 & 4.9 & 1.9 & 0.0 & 0.0 & 0.0 & 0.0 & 0.0 & 0.0 & 3.9 \\
\hline 北山秋 & 13.9 & 5.0 & 39.6 & 0.0 & 7.9 & 2.0 & 2.0 & 2.0 & 0.0 & 0.0 & 3.0 & 2.0 & 22.8 \\
\hline 三条春 & 4.8 & 1.9 & 0.0 & 6.7 & 0.0 & 4.8 & 1.0 & 6.7 & 3.8 & 2.9 & 5.8 & 7.7 & 53.8 \\
\hline 三条夏 & 4.0 & 1.0 & 3.0 & 4.0 & 6.9 & 6.9 & 4.0 & 1.0 & 5.0 & 3.0 & 7.9 & 5.9 & 47.5 \\
\hline 三条秋 & 8.7 & 0.0 & 1.9 & 3.8 & 4.8 & 4.8 & 1.9 & 3.8 & 6.7 & 1.0 & 3.8 & 6.7 & 49.0 \\
\hline 来訪目的 & 散 & & 休念 & & 運動 & & 解勤通学 & & 花見 & & 紅葉 & & の他 \\
\hline 来訪頻度 & 毎 & & $1 \sim 3$ & 3 回 & 週 4 6 [ & & 月数回 & & 年数回 & & 刃めて & & 年 1 回 \\
\hline & 35 & & $\overline{1.6}$ & & 0.0 & & 0.0 & & 43.4 & & 0 & & 16.4 \\
\hline 春 & 11 & & 22.3 & & 3.6 & & 21.4 & & 31.3 & & 0 & & 1.8 \\
\hline & 68 & & 0.0 & & 28.4 & & 1.8 & & 0.0 & & .0 & & 0.9 \\
\hline 口复 & 55 & & 19.4 & & 18.4 & & 2.9 & & 3.9 & & 0.0 & & 0.0 \\
\hline & 54 & & 1.8 & & 12.5 & & 2.7 & & 0.0 & & 9.8 & & 18.8 \\
\hline & 12 & & 20.8 & & 18.8 & & 23.8 & & 16.8 & & 4.0 & & 3.0 \\
\hline & 24 & & 1.7 & & 2.6 & & 3.5 & & 52.2 & & 0.0 & & 15.7 \\
\hline & 3. & & 10.6 & & 3.8 & & 20.2 & & 51.0 & & 7.7 & & 2.9 \\
\hline & 44 & & 2.8 & & 4.6 & & 8.3 & & 0.0 & & 0.0 & & 40.4 \\
\hline & 14 & & $11 . \mathrm{S}$ & & 6.9 & & 21.8 & & 29.7 & & 14.9 & & 0.0 \\
\hline & 53 & & 5.0 & & 6.9 & & 4.0 & & 0.0 & & 9.9 & & 20.8 \\
\hline & 4. & & 12.5 & & 5.8 & & 21.2 & & 37.5 & & 11.5 & & 6.7 \\
\hline
\end{tabular}

※ 北山 : 北山大橋 北大路大橋区間, 三条 : 三条大橋 四条大橋区間 $/$

住所府内外以外は京都市区名／来訪目的，頻度は上段 : 目的，下段 : 頻度 $/ n=625$

う質問を設け，五段階尺度の評価とし，どのような点が京都らし いと思うかという理由を自由回答してもらった。

回収したアンケートは各項目を単純集計し, 京都らしさの有無 と季節における魅力要素については，それぞれの季節における回 答の特徵を確認するため, $\chi^{2}$ 検定と残差分析を行った。また, 来訪者の属性と各回答のクロス集計等を行い, その差異を調べた。

\section{（4）印象評価実験とプロフィール分析，因子分析}

利用者の河川空間に対する印象を把握するためにSD 法 ${ }^{25}$ によ る印象評価実験をアンケート調査と同時に同被験者に対し行った。 なお, SD 法に用いる形容詞 20 対は, 既往研究 26, 27) を参考に選 択した。形容詞間は 5 段階評価 $(2,1,0,-1,-2)$ で 2 と- 2 は「かなり」, 1 と- 1 が「やや」０が「どちらでもないとした。 回答の結果からプロフィール分析と因子分析を行った。プロフィ ール分析は SD 法より得点の平均值を各区間の評価得点とし，評 価プロフィール曲線を作成した。また, 各区間において, 各形容 詞の評価に有意差があるかを調べるため，季節間で分散分析およ びTukey Kramer 法の多重比較を行った ${ }^{28)}$ 。プロフィール分析 による結果を活用し，因子分析を行った。因子分析による因子抽 出法は，最尤法とバリマックス回転を用いた $\left.{ }^{29}, 30\right) 。$ 
表－4 鴨川における観光資源 : 分類別の上位 5 項目と項目比率

\begin{tabular}{|c|c|c|c|c|c|c|c|c|c|}
\hline \multicolumn{2}{|c|}{ 活用性 } & \multicolumn{2}{|c|}{ 生物- 自然 } & \multicolumn{2}{|c|}{ 景観 - 環境 } & \multicolumn{2}{|c|}{ 感情 - 情緒 } & \multicolumn{2}{|c|}{ その他 } \\
\hline 歩きやすい & $3.2 \%$ & 鳥 & $12.3 \%$ & 景観 & $19.5 \%$ & 水の綺麗さ & $11.0 \%$ & すべて & $1.8 \%$ \\
\hline カップル & 2.4 & 川 & 11.4 & 歩道·整備 & $4.8 \%$ & 季節変化 & $6.6 \%$ & ;前 & $0.6 \%$ \\
\hline 散歩できる & $1.6 \%$ & 桜 & $11.2 \%$ & 川林 & $3.4 \%$ & 静 & $3.2 \%$ & 人気 & $0.2^{\circ}$ \\
\hline 座れる & $1.3 \%$ & 自然 & $10.2 \%$ & 京都らしさ & $22 \%$ & 空気 & $2.1 \%$ & -イオン & $0.2^{\circ}$ \\
\hline 它見 & $1.3 \%$ & 水の豊かさ & $10.1 \%$ & 街道欢 & $1.9 \%$ & のんびり & $2.1 \%$ & & \\
\hline 83 & & 57 & & 28 & & 20 & & & \\
\hline $6.6^{\circ}$ & & 45.7 & & 22. & & 23.5 & & & \\
\hline
\end{tabular}

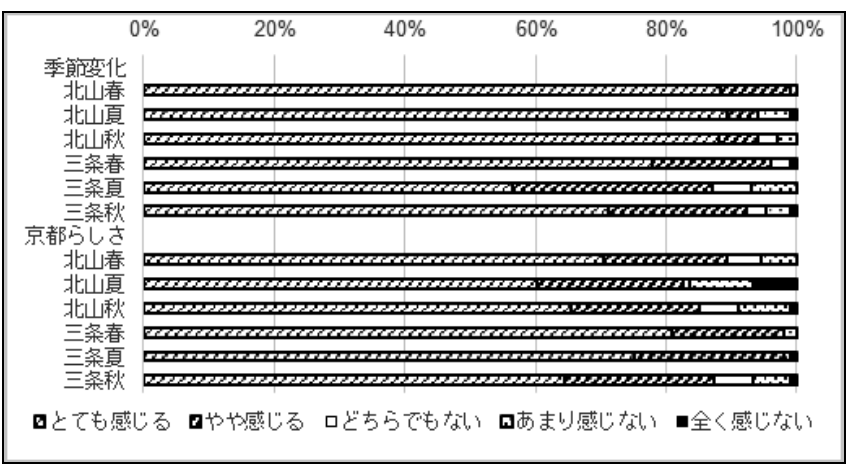

図ー3甲鴨川における「季節変化」「京都らしさ」の認識度

\section{3. 結果並びに考察}

\section{（1）予備調査}

表一2 には予備調査によって抽出した景観構成要素の上位 10 位までの結果を示した。有効回答率は $68.0 \%$ あるる。『川』つ いては,「水面の様子」が最も高い值となり, 次いで,「水の音」, 「泠たさ」「涼しさ」,「水鳥」、飛び石」という結果であった。 『植物』については,「紅葉」が最も高く, 次いで，「草花」「「桜」， 「色 (緑)」,「そよぐ葉音」という結果となった。『生物』につい ては,「鳥」が最も高く, 次いで「虫」,「人々の行動」,「魚」,「鳴 き声」であった。『遠景』については,「山」が最も高く，次いで 「建物」,「街並み」,「雲(形)」,「送り火」,「山の紅葉」であった。 この予備調查は，本調查の設問である「今の季節（調查時）にお ける鴨川の魅力」の提示項目を設定するために行ったものであり， この結果から, 各要素の上位 $5 つ$ 項目および「その他」の自由 回答欄を加えた各 6 項目をアンケート用紙への提示項目とした。

\section{（2）アンケート調査}

表－3は，被験者の属性データを示したものである。

被験者は，春，夏，秋と 3 季節での調查合計が，北山・北大路 区間で 316 人となり，三条・四条区間で 309 人，有効回答率はそ れぞれ $99.7 \%$ と $98.7 \%$ であった。

性別では，どちらの区間をみても，春と秋は女性が多く，夏は 男性が多い結果であった。年齢をみると，北山・北大路区間では どの季節においても 60 代以上の年配世代の利用が多く, 50 代や 70 代も比較的多い結果であった。春の季節のみは 20 代も多く来 訪していた。三条・四条区間では, どの季節でも若い世代の利用 が多いことが示されたが，秋では 70 代，60 代の年配世代の利用 が $45.2 \%$ と半数近くを占める結果であった。

居住地では, 北山・北大路区間は春, 夏, 秋ともに北区が $38.4 \%$, $71.8 \% ， 39.6 \%$ と最も高かったことから，季節に関係なく近隣住 民による利用が多いことが示された。三条・四条区間は春，夏， 秋ともに府外が $53.8 \%, 47.5 \%, 49.0 \%$ と最も高かった。よって， 季節に関係なく京都府外からの来訪者が多いといえる。

来訪目的をみると，北山・北大路区間の春は「花見」が最も高 く $43.4 \%$, 次いで「散歩」が $35.8 \%$ であった。夏は「散歩」が最 も高く $68.8 \%$, 秋については「散歩」が最も高く $54.5 \%$ であった。 三条・四条区間の春は「花見」が最も高く $52.2 \%$, 次いで「散歩」 が $24.3 \%$ で，夏は「散歩」が最も高く $44.0 \%$ であた。秋につい
表—5 季節ごとにみた鴨川の京都らしさの認識度 : $\chi^{2}$ 検定結果

\begin{tabular}{|c|c|c|c|c|c|c|c|c|c|}
\hline & & $\begin{array}{l}\text { とても } \\
\text { 感じる }\end{array}$ & $\begin{array}{c}\text { やや } \\
\text { 感じる }\end{array}$ & $\begin{array}{l}\text { どちらで } \\
\text { もない }\end{array}$ & $\begin{array}{c}\text { あまり感 } \\
\text { じない }\end{array}$ & $\begin{array}{c}\text { 全く感じ } \\
\text { ない }\end{array}$ & $x^{2}$ 值 & $p$ 值 & $\begin{array}{l}\text { 判 } \\
\text { 定 }\end{array}$ \\
\hline 北山 & $\begin{array}{l}\text { 春 } \\
\end{array}$ & $71 \%$ & $19 \%$ & $5 \%$ & $5 \%$ & $0 \%$ & & & \\
\hline . & 夏 & $60 \%$ & $22 \%$ & $7 \%$ & $10 \%$ & $1 \%$ & 3.874 & 0.868 & \\
\hline 北大路 & 秋 & $65 \%$ & $20 \%$ & $6 \%$ & $8 \%$ & $1 \%$ & & & \\
\hline 三条 & 春 & $\uparrow 81 \%$ & $17 \%$ & $0 \%$ & $2 \%$ & $0 \%$ & & & \\
\hline . & 夏 & $75 \%$ & $23 \%$ & $1 \%$ & $1 \%$ & $0 \%$ & 18.228 & 0.020 & * \\
\hline 四条 & 秋 & $\downarrow 64 \%$ & $23 \%$ & $\uparrow 6 \%$ & $\uparrow 6 \%$ & $1 \%$ & & & \\
\hline
\end{tabular}

※ **: $p<0.01,{ }^{*}: p<0.05$ 自由度は全て $8, \uparrow$ け有意に高く、ฟは有意に低い

ても「散歩」が最も高く $53.5 \%$ であった。

来訪頻度は，北山・北大路区間の春は「年数回」が最も高く $31.3 \%$, 次いで「週 1 3」が $22.3 \%$, 夏は「毎日」が最も高く $55.3 \%$, 次に「週 1 3」が $19.4 \%$, 秋は「月数回」が最も高く $23.8 \%$ ，「週 1〜3」が 20.8\%であった。北山・北大路区間は季節 によって利用者の頻度が異なる結果となった。三条・四条区間は どの季節においても，「年数回」が最も高く, 次いで「月数回」の 順であった。「毎日」や「週 4〜6回」利用している人は少ない傾 向にあった。なお，両区間とも，年間を通じての来訪者，年数度 の来訪者, 来訪経験の有無等によっての各設問の回答結果が影響 を受けると考えられたが, それぞれに有意な差はみられなかった。

表－4には，自由回答による鴨川の観光資源を分類し，その結 果をまとめた。「景観」が全体の $19.5 \%$ で最も多く，次いで「鳥」

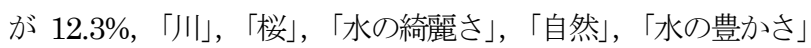
が 10\%以上の回答割合であった。全体を大別してみると，自然に 関わる要素の豊富さに対する回答が $45.7 \%$ と最も多い結果となり, 鴨川全体の観光的価值のある要素として，自然的要素への意識が 高いと考えられた。

図-3 には鴨川における季節変化の認識度についての回答割合 を示した。季節の変化をとても感じる, やや感じるという回答は 三条・四条区間の夏が 8 割以上であるほかは，両区間とも，9割 以上の割合を占める結果であった。

季節を感じる空間づくりの重要性については, 全体の $94 \%$ 要と回答し, どのような点で重要か尋ねた結果, 「落ち着き」や「安 らぎ」など情緒的な側面から重要だという回答が $29 \%$ と最も多か った。次いで「観光」にとって重要だという回答が $21 \%$,「健康」 が $15 \%$,「日本らしさの表現」が $8 \%$ であった。重要でないと回 答した理由としては，無理に造らなくても良い，自然のままでよ いといった意見が寄せられた。

同図-3 には，併せて，鴨川における京都らしさの認識度に関 する結果を示した。京都らしさをとても感じる，やや感じるとい う回答は8 割以上の割合を占める結果であった。

表-5には, 鴨川における京都らしさの認識度について, 春・夏・ 秋の季節ごとに $\chi^{2}$ 検定を行った結果を示した。春の三条・四条 区間で「京都らしさをとても感じる」という回答割合が $81 \%$ $(p<0.05)$ と有意に高く, 北山・北大路区間では有意な差がみ られなかった。この結果，北山・北大路区間では春・夏・秋の季 節ごとに比較した京都らしさの認識度に大きな違いがなく，三 条・四条区間では桜並木などの景観が春の京都らしさを感じると いら回答に影響を与えていると考えられた。さらに，京都らしさ を「感じる」と答えた人に理由を尋ねた結果，三条・四条区間で 最も多かったのが「街並み」 $(20.9 \%)$ であり，次いで「川床」

$(12.9 \%)$, 「桜」 $(8.2 \%)$, 「の姿」 $(5.5 \%)$, 「水」 $(4.6 \%)$ で あった。また北山・北大路区間で最も多かったのが「山並み」 (14.3\%) であり, 次いで「鴨川そのもの（“鴨川”自体が京都の イメージ $) 」(10.9 \%), 「$ 自然」 $(9.1 \%)$,「桜」 $(7.9 \%)$,「水」 (7.9\%) であった。これらの結果から, 「京都らしさ」を想起さ せる要因は区間によって異なることが伺えた。特に，三条・四条 区間においては高い建築物がなく，京町家などの木造建築が建ち 
表一6 季節ごとにみた鴨川の魅力要素 : $\chi^{2}$ 検定結果

\begin{tabular}{|c|c|c|c|c|c|c|c|c|}
\hline \multicolumn{9}{|c|}{ 北山·北大路区間 } \\
\hline 川 & 水の音 & $\begin{array}{l}\text { 水面様 } \\
\text { 子 }\end{array}$ & 水鳥 & 飛沰 & 冷たさ & $\chi^{2}$ 値 & p值 & 判定 \\
\hline 春 & $53 \%$ & $\uparrow 35 \%$ & $29 \%$ & $13 \%$ & $\downarrow 0 \%$ & & & \\
\hline 夏 & $51 \%$ & $18 \%$ & $32 \%$ & $13 \%$ & $5 \%$ & 17.932 & 0.022 & * \\
\hline 秋 & $40 \%$ & $22 \%$ & $\uparrow 44 \%$ & $12 \%$ & $6 \%$ & & & \\
\hline 植物 & 桜 & $\begin{array}{c}\text { 木々の } \\
\text { 緑 }\end{array}$ & 紅葉 & 草花 & $\begin{array}{l}\text { 葉擦れ: } \\
\text { 木々の音 }\end{array}$ & $\chi^{2}$ 值 & $p$ 値 & 判定 \\
\hline 春 & $\uparrow 93 \%$ & $\downarrow 22 \%$ & $\downarrow 3 \%$ & $13 \%$ & $\downarrow 2 \%$ & & & \\
\hline 夏 & $\downarrow 1 \%$ & $\uparrow 55 \%$ & $\downarrow 1 \%$ & $\uparrow 17 \%$ & $5 \%$ & 388.604 & 0.000 & ** \\
\hline 秋 & $10 \%$ & $9 \%$ & $\uparrow 87 \%$ & $12 \%$ & $7 \%$ & & & \\
\hline 生物 & 鳥 & 魚 & 虫 & 鳴き声 & 人の行動 & $\chi^{2}$ 値 & $p$ 值 & 判定 \\
\hline 春 & $82 \%$ & $15 \%$ & $5 \%$ & $13 \%$ & $16 \%$ & & & \\
\hline 夏 & $\downarrow 65 \%$ & $25 \%$ & $\uparrow 13 \%$ & $14 \%$ & $9 \%$ & 17.037 & 0.030 & * \\
\hline 秋 & $75 \%$ & $19 \%$ & $\downarrow 2 \%$ & $13 \%$ & $8 \%$ & & & \\
\hline 遠景 & 山亚み & 街並み & 送り火 & 雲 & 山の紅葉 & $\chi^{2}$ 值 & $p$ 値 & 判定 \\
\hline 春 & $\uparrow 84 \%$ & $6 \%$ & $\downarrow 3 \%$ & $10 \%$ & $\downarrow 2 \%$ & & & \\
\hline 夏 & $72 \%$ & $4 \%$ & $\uparrow 17 \%$ & $9 \%$ & $\downarrow 0 \%$ & 75.371 & 0.000 & ** \\
\hline 秋 & $\downarrow 68 \%$ & $6 \%$ & $\downarrow 2 \%$ & $8 \%$ & $\uparrow \mathbf{2 8 \%}$ & & & \\
\hline \multicolumn{9}{|c|}{ 三条·四条区間 } \\
\hline 植物 & 桜 & 木々の緑 & 紅葉 & 草花 & $\begin{array}{l}\text { 葉察れ - } \\
\text { 木々の音 }\end{array}$ & $\chi^{2}$ 值 & $p$ 値 & 判定 \\
\hline 春 & $\uparrow 94 \%$ & $\downarrow 20 \%$ & $\downarrow 0 \%$ & $8 \%$ & $\downarrow 2 \%$ & & & \\
\hline 夏 & $\downarrow 0 \%$ & $\uparrow 61 \%$ & $\downarrow 1 \%$ & $\uparrow 12 \%$ & $7 \%$ & 411.593 & 0.000 & ** \\
\hline 秋 & $\downarrow 0 \%$ & $\sqrt{5} \%$ & $\uparrow 75 \%$ & $5 \%$ & $\uparrow 10 \%$ & & & \\
\hline 遠景 & 山並み & 街並み & 送り火 & 雲 & 山の紅葉 & $\chi^{2}$ 值 & $p$ 値 & 判定 \\
\hline 春 & $\uparrow 61 \%$ & $27 \%$ & $0 \%$ & $\downarrow 3 \%$ & $\downarrow 0 \%$ & & & \\
\hline 夏 & $\downarrow 52 \%$ & $35 \%$ & $\uparrow 5 \%$ & १22\% & $\downarrow 1 \%$ & 44.994 & 0.000 & ** \\
\hline 秋 & $49 \%$ & $28 \%$ & $0 \%$ & $8 \%$ & $\uparrow 9 \%$ & & & \\
\hline
\end{tabular}

並ぶ景観そのものが京都らしさとして認識されていること，北 山・北大路区間では遠くの山並みに加えて, 鴨川の自然的な要素 を含む河川敷の囲繞景観 31）が京都らしさを印象付けていること が考えられた。

表一6 に季節ごとにみた鴨川の各魅力要素の全被験者に占める 回答人数の割合と, $\chi^{2}$ 検定の結果有意差が得られた項目のみを 併せて示した。両区間に共通して, 春の「桜」（北山・北大路区間 $93 \%$ ，三条・四条区間 $94 \%$ ), 夏の「木々の緑」(北山・北大路区 間 55\%，三条・四条区間 61\%）と「草花」（北山・北大路区間 $17 \%$ ，三条・四条区間 $12 \%$ ), 秋の「紅葉」(北山・北大路区間 $87 \%$ ，三条・四条区間 $75 \%$ ）といった植物が各季節を特徵づける 魅力要素となっていた。また遠景について，春は山全体の印象で ある「山並夕」(北山・北大路区間 84\%，三条・四条区間 61\%) が多く選ばれているのに対し,夏は季節の行事に関わる要素の「送 り火」（北山・北大路区間 $17 \%$ ，三条・四条区間 $22 \%$ ）が，また 秋は山の植生に関わる「山の紅葉」（北山・北大路区間 $28 \%$ ，三 条・四条区間 9\%) がそれぞれ多く選ばれており，季節ごとに変 化する山の様相が，季節による遠景の魅力の違いに反映されてい ると考えられた。さらに夏にのみ「虫」(北山・北大路区間 13\%) が，秋にのみ「水鳥」（北山・北大路区間 44\%）がそれぞれ多く 選ばれ，生物が季節を感じさせる要因のひとつとして作用してい た。これらのことから，鴨川の季節の魅力要素は，各季節を特徵 づける植物や季節ごとに様相が変化する生物を筆頭に，季節を象 徵する行事に関わる要素なども挙げられ，「自然的な側面」のみな らず「文化的な側面」に関わる要素も見られる結果が得られた。

\section{（3）印象評価実験とプロフィール分析，因子分析}

SD 法の結果は，表一7 に示した。季節間で分散分析および多 重比較を行ったところ，北山・北大路区間では，春と秋の「変化 にとんだ」、「多彩色な」,「季節感のある」の印象評価が高く, 夏 に比べて有意な差がみられた。夏は緑が大半を占めるため春や秋 と比べて色彩は単調な印象を受けるものと考えられる。しかし, 「好きな」,「魅力的」,「美しい」,「心地よい」をみてみると， 3 季節ともに高得点を得られており, 単調という印象が一概に負の
表一7 形容詞対の平均値と標準偏差

\begin{tabular}{|c|c|c|c|c|c|c|c|c|c|c|c|c|}
\hline 区間 & \multicolumn{6}{|c|}{ 北山·北大路区間 } & \multicolumn{6}{|c|}{ 三条·四条区間 } \\
\hline 季節 & \multicolumn{2}{|c|}{ 春 } & \multicolumn{2}{|c|}{ 夏 } & \multicolumn{2}{|c|}{ 秋 } & & \multicolumn{2}{|c|}{ 百 } & \multicolumn{2}{|c|}{ 秋 } \\
\hline 平均值 $\cdot 2$ 標 & 1 & 2 & 1 & 2 & 1 & 2 & 1 & 2 & 1 & 2 & 1 & 2 \\
\hline 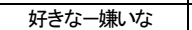 & t & & & & & & & & & 47 & & \\
\hline 的- & t & 38 & & 3 & & & 73 & 58 & 1.60 & 60 & & \\
\hline & 82 & 0. & & 38 & 88 & & 71 & 39 & 1.36 & 67 & 36 & \\
\hline & 34 & 0.37 & 37 & 8 & & & & 63 & 1.58 & oy & Ju & \\
\hline & 11 & 0.88 & & 19 & & 1.02 & 69 & 1.0 & 0.35 & 1.01 & 31 & 16 \\
\hline & 37 & 0.74 & 16 & 0.87 & & 0.84 & 33 & & 1.11 & 0.77 & 1.06 & 95 \\
\hline ぎやカ & 44 & 1.28 & 0.31 & 1.15 & -0.97 & 1.07 & 0.25 & 1.28 & 0.13 & 1.25 & -0.44 & 1.3 \\
\hline 歴史的な一現代白 & 43 & 0.93 & 0.69 & 1.06 & 0.44 & 0.96 & 86 & 0.96 & 0.87 & 0.99 & 0.72 & 0.9 \\
\hline 多彩色な一単彩 & 10 & 1.00 & 0.48 & 1.37 & 1.35 & 1.02 & 80 & 1.01 & -0.01 & 1.14 & -0.04 & 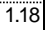 \\
\hline 自然的な一人 & 39 & 0.81 & 1.18 & 1.06 & 1.16 & 1.15 & 0.79 & 1.08 & 0.70 & 1.04 & 0.66 & 1.1 \\
\hline 派手な一 & 53 & 0.80 & -0.59 & 0.90 & -0.82 & 0.93 & -0.80 & 0.86 & -0.80 & 0.77 & -1.00 & 0.1 \\
\hline 開放的な一閉鎖的 & 1.54 & 0.67 & 1.40 & 0.86 & 1.61 & 0.65 & 1.26 & 0.81 & 1.36 & 0.77 & 1.24 & 0.9 \\
\hline 明るい一暗い & 1.61 & 0.54 & 1.52 & 0.74 & 1.71 & 0.61 & 1.56 & 0.64 & 1.14 & 0.80 & .02 & 0.8 \\
\hline 圧迫感無一圧迫感 & 1.78 & 0.48 & 1.68 & 0.64 & 1.89 & 0.34 & 1.65 & 0.69 & 1.68 & 0.55 & 1.71 & 0.3 \\
\hline 緑が多いー緑が少 & 1.70 & 0.53 & 1.81 & 0.54 & 1.6 & 0.66 & 1.15 & 0.84 & 1.17 & 0.88 & 1.00 & 1.0 \\
\hline ーしたーは & 1.06 & 0.86 & 1.08 & 0.97 & 1.3 & 0.85 & 1.00 & 0.97 & 0.89 & 1.00 & 0.92 & \\
\hline 安定したー不 & 1.37 & 0.76 & 1.44 & 0.82 & 1.62 & 0.72 & 1.33 & 0.74 & 1.09 & 0.84 & 1.41 & 0.8 \\
\hline 風情の有一風 & 1.72 & 0.56 & 1.54 & 0.80 & 1.7 & 0.60 & 1.60 & 0.58 & 1.62 & 0.65 & 60 & \\
\hline 酯 & 1.71 & 0.59 & 1.53 & 0.73 & 1.6 & 0.64 & 1.48 & 0.65 & 1.36 & 0.77 & 1.37 & 0.8 \\
\hline 季節感有一季節感 & 1.88 & 0.33 & 1.70 & 0.67 & 1.86 & 0.40 & .83 & 0.40 & 1.44 & 0.71 & 1.57 & 0.5 \\
\hline
\end{tabular}

イメージではないと考えられた。また，秋の「静かな」印象が春 夏と比べて有意な差がみられた。来訪目的をみると, 春は花見, 夏はスポーツといった目的の来訪者が多く見られ，人々の活動面 でも秋と比べると賑やかさを持っていると推察される。三条・四 条区間では春の「美しい」,「多彩色な」,「明るい, 「季節感のあ る」の印象評価が高く, 夏と秋に比べて有意な差がみられた。こ れは両岸の桜が影響していると考えられ，華やかで明るい印象を 与えていると推察される。秋の「静かな」という印象は, 春夏に 比べて有意な差がみられた。これは春の花見や夏の川床などの賑 やかさはなく,落ち着いた静かな雰囲気によるものと推察された。

表一8，9には，季節ごとに因子分析の結果を示した。

表一 8 に示した北山・北大路区閒の春は 3 因子が抽出され，「桜 並木景観への印象」,「河川敷空間の開放性」, 「心情性」と命名し た。夏は 3 因子が抽出され,「川全体の情緒性」,「躍動性」,「平 稳性」と命名した。秋は 3 因子が抽出され,「快適性」,「調和性」,

「平穏性」と命名した。最も空間を特徵付けている第 1 因子の評 価項目は, 春は表一6 でも春の魅力要素として多く挙げられてい た半木の道の桜並木景観の統一性をはじめ, 賀茂街道並木の歴史 性, 枝垂れ桜の風情, 表一7 でも印象評価が有意に高かった桜色 や新芽の緑色といった春の多彩色さなどから成っていると判断し,

「桜並木景観への印象」と解釈した。夏は水辺と緑地空間の見た 目の印象に加えて空間から受ける心情的な要素を含んでいること, 「木々の緑」が魅力として抽出されてなおかつ分散分析の結果か ら夏の緑は単彩色で単調ではあるものの好まれる傾向にあったこ とから, 緑も含めた川全体に関わる情緒的な印象だと判断し，「川 全体の情緒性」と解釈した。秋は空間として利用される上で, 散 歩を目的とする人が多かったことや，夏季と比較すると気温が低 く, 訪れる人々が空間に求める要素として体感的な快適さが考え られたことから，「快適性」と解採した。これら北山・北大路区間 の空間の印象は季節によって異なる結果が得られた。

一方，表一 9 に示した三条・四条区間においては，季節によっ て各空間を印象付ける要素に似通った傾向が見られた。春は，4 因子が抽出され, 「街並夕と桜並木への印象」,「心情性」,「桜並 木への印象」,「開放性」と命名した。夏は，5因子が抽出され, 「街並みと木々の緑への印象」,「心情性」,「開放性」,「自然性」, 「躍動性」と命名した。秋は，5因子が抽出され，「街並みと紅葉 への印象」,「心情性」,「開放性」,「温和性」,「躍動性」と命名し た。それぞれの第 1 因子は, 「安定した」や「風情がある」,「統 一した」などの負荷量が高く, 北山・北大路区間には存在しない 
表一8 北山・北大路区間の春，夏，秋の因子分析の結果

\begin{tabular}{|c|c|c|c|}
\hline \multicolumn{4}{|c|}{ 春 } \\
\hline 変数 & 因子1 & 因子2 & 因子3 \\
\hline 命名 & $\begin{array}{c}\text { 桜前木影観 } \\
\text { への印象 }\end{array}$ & \begin{tabular}{|c} 
河川溥空間 \\
の開放性
\end{tabular} & 心情性 \\
\hline 統一したーばらばらな & 0.714 & -0.011 & 0.185 \\
\hline 潤いの有－潤いの無 & 0.585 & 0.043 & 0.331 \\
\hline 安定したー不安定な & 0.550 & 0.118 & 0.019 \\
\hline 緑が多いー䋚が少ない & 0.537 & 0.359 & 0.127 \\
\hline 柔らかい一硬い & 0.528 & 0.317 & 0.094 \\
\hline 歴史的な一現代的な & 0.447 & -0.021 & 0.148 \\
\hline 変化にとんだ一単調な & 0.428 & 0.204 & 0.191 \\
\hline 自然的な一人工的な & 0.389 & 0.111 & 0.091 \\
\hline 多彩色な一単彩色な & 0.364 & 0.235 & 0.268 \\
\hline 開放的な一閉鎖的な & 0.312 & 0.743 & 0.014 \\
\hline 明るい一暗い & 0.384 & 0.688 & 0.259 \\
\hline 圧迫感無一圧迫感有 & 0.326 & 0.645 & 0.117 \\
\hline 心地よい一不快な & 0.229 & 0.400 & 0.211 \\
\hline 派手なーひかえめな & -0.070 & 0.258 & 0.059 \\
\hline にぎやかなー静かな & 0.002 & 0.217 & 0.062 \\
\hline 魅力的一魅力的で無 & 0.262 & 0.170 & 0.706 \\
\hline 美しい一醜い & -0.022 & 0.408 & 0.659 \\
\hline 好きな一嫌いな & 0.223 & 0.106 & 0.598 \\
\hline 風情の有一風情の無 & 0.527 & 0.045 & 0.547 \\
\hline 季節感有一季節感無 & 0.316 & 0.293 & 0.436 \\
\hline 固有値 & 3.296 & 2.365 & 2.220 \\
\hline 寄与率 & $16.5 \%$ & $11.8 \%$ & $11.1 \%$ \\
\hline 累積寄与率 & $16.5 \%$ & $28.3 \%$ & $39.4 \%$ \\
\hline
\end{tabular}

\begin{tabular}{|c|c|c|c|}
\hline \multicolumn{4}{|c|}{ 夏 } \\
\hline 変 数 & 因子1 & 因子2 & 因子3 \\
\hline 命名 & $\begin{array}{c}\text { 川全体の情 } \\
\text { 緒性 }\end{array}$ & 躍動性 & 平穏性 \\
\hline 安定したー不安定な & 0.764 & 0.203 & 0.043 \\
\hline 潤いの有一潤いの無 & 0.728 & 0.395 & 0.012 \\
\hline 風情の有一風情の無 & 0.718 & 0.410 & 0.046 \\
\hline 明るい一暗い & 0.670 & 0.334 & 0.183 \\
\hline 統一したーばらばらな & 0.639 & 0.177 & 0.041 \\
\hline 美しい一醜い & 0.610 & 0.500 & 0.119 \\
\hline 魅力的一魅力的でない & 0.594 & 0.567 & 0.097 \\
\hline 開放的な一閉鎖的な & 0.551 & 0.156 & 0.021 \\
\hline 季節感有一季節感無 & 0.535 & 0.507 & 0.028 \\
\hline 心地よいー不快な & 0.514 & 0.496 & 0.179 \\
\hline 歴史的な一現代的な & 0.482 & 0.210 & -0.084 \\
\hline 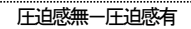 & 0.478 & 0.376 & 0.129 \\
\hline 柔らかいー硬い & 0.440 & 0.415 & -0.044 \\
\hline 自然的な一人工的な & 0.355 & 0.168 & 0.036 \\
\hline 多彩色な一単彩色な & 0.352 & 0.287 & -0.040 \\
\hline 好きな一嫌いな & 0.180 & 0.931 & -0.038 \\
\hline 緑が多い一緑が少ない & 0.350 & 0.771 & 0.027 \\
\hline 変化にとんだー単調な & 0.412 & 0.417 & -0.160 \\
\hline にぎやかなー静かな & 0.172 & -0.043 & -0.781 \\
\hline 派手なーUかえめな & -0.207 & 0.029 & -0.421 \\
\hline 固有値 & 5.364 & 3.714 & 0.940 \\
\hline 寄与率 & $26.8 \%$ & $18.6 \%$ & $4.7 \%$ \\
\hline 累積寄与率 & $26.8 \%$ & $45.4 \%$ & $50.1 \%$ \\
\hline
\end{tabular}

\begin{tabular}{|c|c|c|c|}
\hline \multicolumn{4}{|c|}{ 秋 } \\
\hline 変数 & 因子1 & 因子2 & 因子3 \\
\hline 命名 & 快適性 & 調和性 & 平穏性 \\
\hline 圧迫感無一厓迫感有 & 0.859 & 0.117 & 0.211 \\
\hline 心地よいー不快な & 0.686 & 0.583 & 0.145 \\
\hline 季節感有一季節感無 & 0.663 & 0.018 & 0.482 \\
\hline 好きな一嫌いな & 0.663 & 0.608 & 0.052 \\
\hline 明るい一暗い & 0.657 & 0.203 & 0.244 \\
\hline 魅力的一魅力的でない & 0.519 & 0.481 & 0.046 \\
\hline 多彩色な一単彩色な & 0.158 & 0.152 & 0.135 \\
\hline 派手な一ひかえめな & -0.267 & -0.025 & -0.005 \\
\hline 美しい一醜い & -0.014 & 0.740 & 0.252 \\
\hline 統ーしたーばらばらな & 0.169 & 0.479 & 0.277 \\
\hline 変化にとんだ一単調な & 0.254 & 0.422 & 0.187 \\
\hline 柔らかい一硬い & 0.203 & 0.362 & 0.271 \\
\hline にぎやかなー静かな & -0.018 & -0.162 & 0.001 \\
\hline 安定したー不安定な & 0.121 & 0.447 & 0.638 \\
\hline 風情の有一風情の無 & 0.407 & 0.074 & 0.593 \\
\hline 緑が多い一緑が少ない & 0.093 & 0.327 & 0.540 \\
\hline 潤いの有一潤いの無 & 0.205 & 0.328 & 0.458 \\
\hline 自然的な一人工的な & 0.014 & 0.039 & 0.376 \\
\hline 開放的な一閉鎖的な & 0.214 & -0.005 & 0.365 \\
\hline 歴史的な一現代的な & -0.149 & 0.171 & 0.218 \\
\hline 固有値 & 3.319 & 2.583 & 2.211 \\
\hline 寄与率 & $16.6 \%$ & $12.9 \%$ & $11.1 \%$ \\
\hline 累積寄与率 & $16.6 \%$ & $29.5 \%$ & $40.6 \%$ \\
\hline
\end{tabular}

\begin{tabular}{|c|c|c|c|c|}
\hline \multicolumn{5}{|c|}{ 春 } \\
\hline 変数 & 因子1 & 因子2 & 因子3 & 因子4 \\
\hline 命名 & \begin{tabular}{|c|} 
街並みと \\
桜並木 \\
の印象 \\
\end{tabular} & 心情性 & $\begin{array}{c}\text { 桜並木 } \\
\text { への印 } \\
\text { 象 } \\
\end{array}$ & 開放性 \\
\hline 安定したー不安定な & 0.768 & 0.253 & -0.061 & 0.113 \\
\hline 風情の有一風情の無 & 0.560 & 0.267 & 0.204 & -0.031 \\
\hline 季節感有－季節感無 & 0.556 & 0.299 & 0.008 & 0.305 \\
\hline 潤いの有一潤いの無 & 0.546 & 0.275 & 0.140 & 0.228 \\
\hline 柔らかい一硬い & 0.513 & 0.257 & 0.346 & 0.114 \\
\hline 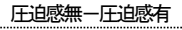 & 0.353 & 0.025 & 0.202 & 0.159 \\
\hline 魀力的一魅力的でない & 0.208 & 0.808 & 0.235 & 0.155 \\
\hline 好きな一嫌いな & 0.165 & 0.760 & 0.134 & 0.168 \\
\hline 美しい一醜い & 0.182 & 0.541 & 0.324 & 0.241 \\
\hline 心地よい一不快な & 0.150 & 0.533 & 0.209 & 0.407 \\
\hline 派手なーひかえめな & -0.154 & -0.331 & 0.160 & 0.100 \\
\hline にきややかなー静かな & -0.174 & -0.380 & 0.172 & 0.001 \\
\hline 変化にとんだー単調な & 0.147 & 0.048 & 0.611 & -0.027 \\
\hline 多彩色な一単彩色な & -0.025 & 0.003 & 0.580 & 0.199 \\
\hline 自然的な一人工的な & 0.082 & 0.040 & 0.574 & 0.097 \\
\hline 歴史的な一現代的な & 0.431 & 0.070 & 0.486 & -0.217 \\
\hline 緑が多いー緑か版ない & 0.332 & 0.080 & 0.461 & 0.24 \\
\hline 明るい一暗い & 0.031 & 0.073 & 0.152 & 0.985 \\
\hline 開放的な－閏鎖的な & 0.150 & 0.109 & 0.044 & 0.437 \\
\hline 統一したーばらばらな & 0.292 & 0.076 & 0.073 & 0.343 \\
\hline 固有值 & 2.513 & 2.467 & 2.021 & 1.9 \\
\hline 寄与率 & $12.6 \%$ & $12.3 \%$ & $10.1 \%$ & $9.6^{\circ}$ \\
\hline 累積寄与率 & $126^{\circ}$ & $24.9 \%$ & $35.0^{\circ}$ & 140 \\
\hline
\end{tabular}

\begin{tabular}{|c|c|c|c|c|c|}
\hline \multicolumn{6}{|l|}{ 表一9 } \\
\hline \multicolumn{6}{|c|}{ 夏 } \\
\hline 変数 & 因子1 & 因子2 & 因子3 & 因子4 & 因子5 \\
\hline 命名 & $\begin{array}{l}\text { 街並みと } \\
\text { 木々の緑 } \\
\text { への印象 }\end{array}$ & 心情性 & 開放性 & 自然性 & 躍動 \\
\hline 柔らかい一硬い & 0.480 & 0.215 & 0.131 & 0.070 & 0.0 \\
\hline 歴史的な一現代的な & 0.419 & 0.110 & 0.164 & 0.303 & 0. \\
\hline 統ーしたーばらばらな & 0.703 & 0.013 & 0.061 & -0.022 & -0.38 \\
\hline 安定したー不安定な & 0.659 & 0.051 & 0.006 & -0.071 & -0 \\
\hline 風情の有一風情の無 & 0.504 & 0.222 & 0.455 & 0.305 & 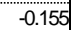 \\
\hline 潤いの有一潤いの無 & 0.568 & 0.162 & 0.338 & 0.105 & -0.0 \\
\hline 季節感有一季節感無 & 0.457 & 0.139 & 0.347 & 0.296 & 0.1 \\
\hline 好きな一嫌いな & 0.217 & 0.758 & 0.080 & 0.067 & \\
\hline 魅力的一魅力的でない & 0.029 & 0.761 & 0.129 & 0.120 & -0. \\
\hline 美しい一醜い & 0.347 & 0.441 & 0.285 & 0.006 & 0.13 \\
\hline 多彩色な一単彩色な & -0.087 & 0.245 & 0.010 & 0.214 & 0.1 \\
\hline 明るいー暗い & 0.259 & 0.377 & 0.370 & 0.141 & 0.28 \\
\hline 開放的な一閉鎖的な & -0.018 & 0.085 & 0.704 & 0.033 & 0.01 \\
\hline 心地よい一不快な & 0.234 & 0.365 & 0.400 & 0.200 & .20 \\
\hline 圧迫感無一圧迫感有 & 0.204 & 0.048 & 0.403 & -0.020 & 0.02 \\
\hline 自然的な一人工的な & 0.037 & 0.198 & 0.035 & 0.968 & -0.14 \\
\hline 緑が多いー緑が少ない & 0.360 & 0.011 & 0.362 & 0.390 & -0.12 \\
\hline 変化にとんだー単調な & 0.218 & 0.334 & -0.024 & 0.264 & .35 \\
\hline 派手なーひかえめな & -0.265 & 0.044 & -0.083 & -0.193 & 156 \\
\hline にきややかなー静かな & -0.105 & -0.143 & 0.068 & -0.004 & 0.62 \\
\hline 固有值 & 2.720 & 2.022 & 1.693 & 1.617 & \\
\hline 寄与率 & $13.6 \%$ & $10.1 \%$ & $8.5 \%$ & $8.1 \%$ & \\
\hline 累積寄与率 & $13.6 \%$ & $23.7 \%$ & $32.2 \%$ & $40.3 \%$ & 47.1 \\
\hline
\end{tabular}

\begin{tabular}{|c|c|c|c|c|c|}
\hline \multicolumn{6}{|c|}{ 秋 } \\
\hline 変数 & 因子1 & 因子2 & 因子3 & 因子4 & 因子5 \\
\hline 命名 & $\begin{array}{c}\text { 街並みと } \\
\text { 紅葉への } \\
\text { 印象 }\end{array}$ & 心情性 & 開放性 & 温和性 & 躍動性 \\
\hline 安定したー不安定な & 0.713 & 0.126 & 0.183 & 0.022 & -0.017 \\
\hline 統一したーばらばらな & 0.680 & 0.188 & 0.063 & 0.062 & -0.053 \\
\hline 風風情の有一風情の無 & 0.585 & 0.297 & 0.018 & 0.139 & -0.069 \\
\hline 潤いの有一潤いの無 & 0.521 & 0.257 & 0.216 & 0.237 & 0.114 \\
\hline 季節感有一季節感無 & 0.493 & 0.271 & 0.177 & 0.305 & 0.093 \\
\hline 緑が多いー緑が少ない & 0.465 & 0.296 & 0.342 & 0.131 & -0.032 \\
\hline 魅力的一魅力的でない & 0.254 & 0.855 & 0.091 & 0.215 & 0.050 \\
\hline 好きな一嫌いな & 0.416 & 0.709 & 0.043 & 0.054 & 0.070 \\
\hline 美しい一醜い & 0.327 & 0.669 & -0.028 & 0.019 & -0.023 \\
\hline 心地よいー不快な & 0.197 & 0.577 & 0.293 & 0.374 & -0.009 \\
\hline 自然的な一人工的な & 0.278 & 0.424 & 0.047 & 0.145 & -0.008 \\
\hline 変化にとんだ一単調な & -0.153 & 0.316 & 0.214 & 0.135 & 0.218 \\
\hline 明るい一暗い & 0.236 & 0.050 & 0.665 & 0.043 & 0.129 \\
\hline 開放的な一閉鎖的な & 0.162 & 0.100 & 0.546 & -0.030 & 0.121 \\
\hline 压迫感無一压自感有 & 0.455 & 0.135 & 0.487 & 0.148 & 0.033 \\
\hline 歴史的な一現代的な & 0.275 & 0.247 & -0.356 & 0.074 & 0.175 \\
\hline 柔らかい一硬い & 0.239 & 0.186 & 0.075 & 0.949 & 0.055 \\
\hline 派手なーひかえめな & -0.094 & -0.180 & 0.119 & -0.281 & 0.196 \\
\hline にぎやかなー静かな & 0.019 & -0.130 & -0.036 & -0.068 & 0.988 \\
\hline 多彩色な一単彩色な & 0.001 & 0.167 & 0.181 & 0.026 & 0.433 \\
\hline 固有値 & 2.961 & 2.864 & 1.536 & 1.433 & 1.355 \\
\hline 寄与率 & $14.8 \%$ & $14.3 \%$ & $7.7 \%$ & $7.2 \%$ & $6.8 \%$ \\
\hline 累積寄与率 & $14.8 \%$ & $29.1 \%$ & $36.8 \%$ & $44.0 \%$ & $50.8 \%$ \\
\hline
\end{tabular}

京町家による街並みの影響が考えられたこと，また「季節感があ る」や「潤いがある」の負荷量が高く，季節を特徵付ける植物の 「桜」や「木々の緑」「紅葉」が影響を与えていることが考えら れ，それぞれ「街並みと桜並木への印象」、「街並みと木々の緑一 の印象」，「街並みと紅葉への印象」と解釈した。

北山・北大路区間と三条・四条区間で印象に違いが見られた原 因として考えられたのは京町家による街並みの有無であった。京 町家による街並みは景観構成要素としては季節による变化をあま り反映せず，なおかつ空間全体の印象に強く寄与するものである 結果が得られたと言える。また同時に，両区間ともに共通して季 節を特徵づける植物もまた空間全体の印象に強く寄与している結 果が得られており，季節感を感じさせる植栽と季節によって印象 が左右されない街並みが空間の印象に強く寄与していることが明 らかになった。

\section{4. 総合考察}

本研究では，鴨川の北山・北大路区間と三条・四条区間の 2 区
間において季節の魅力や印象の変化を明らかにすることを目的と して, 調查対象現地でのアンケート調査を行った。以下, 図一2 に示したフロー図に沿って総合考察を行なう。

利用者が鴨川へ訪れる目的として，両区間ともに春は「花見」 が最も多く, 次いで「散歩」が多い結果が得られた。また, 夏と 秋は両区間とも「散歩」が最も多く，河川緑地空間としての鴨川 は利用者が季節の植物を楽しめる親水空間として機能していた。

鴨川の景観構成要素の魅力を見ると，全体の傾向として「桜」 や「木々の緑」「紅葉」など各季節を特徵づける植物,「虫」や「水 鳥」などの生物, さらに季節の行事に関わる「送り火」などが抽 出された。これより鴨川は前述した親水空間としての機能に加え て，「生物が生息する自然的な側面」が魅力として感じられており， さらに季節を象徴する行事に関わる要素なども魅力として感じら れていることが考えられた。

鴨川の「京都らしさ」について, 両区間ともどの季節でも 8 割 以上の人が鴨川に「京都らしさ」を感じており，季節に関係なく 調査対象区間は地域性の高い空間と考えられた。ここでの京都ら 
しさとは, アンケート回答にも示されたように「街並み」や「山 並み」,「桜」,「川床」といった項目で, これらの存在や要素から 「らしさ」を示したと考えられた。また，三条・四条区間のみ春 における鴨川に対して「京都らしさ」を「とても感じる」人が有 意に多い結果が得られており，なおかつ三条・四条区間において 「街並み」や「川床」が京都らしさを感じる理由として挙げられ ていた。特に，春においては三条・四条区間における特徵的な河 川沿いの「街並み」が，「桜」とともに存在することによって，北 山・北大路区間よりも「京都らしさ」を強く感じさせたのではな いかと推察した。さらに，因子分析の結果から三条・四条区間で は季節に関わらず京町家による街並夕などが「安定感」や「統一 感の印象を与え，なおかつそれに付随して季節の樹木が「季節 感や「潤い」の印象を与えている結果が得られていることから も，「京都らしさ」という地域性を表す要素は季節に関わらず空間 の印象に寄与するが，春の「桜」が伴うことでより地域性を強く 感じさせることが明らかになった。

鴨川の空間全体の印象として, SD 法と分散分析，多重比較の 結果から北山・北大路区間は春と秋の「変化にとんだ」や「多彩 色な」，「季節感のある」の印象が夏に比べて高く，春の「桜」と 秋の「紅葉」が影響したと考えられる。しかし，「好きな」や「鬼 力的」,「美しい, 「心地よいが 3 期ともに高得点であったこと, 夏の景観構成要素の魅力として「木々の緑」が挙げられていたこ とから，夏の単彩色で単調な印象は一概にマイナスのイメージに はつながらないと考えられた。三条・四条区間は, 春の「美しい」 や「多彩色な」,「明るい, 「季節感のある」の印象が夏と秋に比 べて高かった。これは前述した「京都らしさ」に関わる桜並木の 影響と考えられ，空間全体の印象に対して「桜」が強く作用して いることが示唆された。因子分析の結果からは，北山・北大路区 間では季節によって空間全体に対する印象は，春は「桜並木景観 への印象」, 夏は「川全体の情緒性」, 秋は「快適性」と，季節ご とに変化する傾向が見られた。一方，三条・四条区間においては 季節による空間全体の印象は大きくは変化せず，これは北山・北 大路区間には存在しない京町家の「街並外」や，「遠景」が季節に よってあまり変化しないことに関わっていることが考えられた。 さらに「京都らしさ」と絡めると, この季節によって変動しない 印象に加えて季節を特徵づける植物によって空間の季節性と地域 性を表していることが示唆された。

以上より，春と秋は樹木の変化が視覚的に感じやすく自然的な 要素が印象に影響し，夏は樹木が単調であるために川や街並みな ど空間全体の要素が印象に影響することが考えられた。さらに, 街並みや季節を象徴する装置(川床), 行事(送り火)な゙の文化的な 側面が季節ごとの印象に影響していること，それに加えて特に春 の「桜」が地域性を強めていることが明らかになった。

\section{5. おわりに}

本研究では，京都市を北から南へと縦断して流れる鴨川に着目 し，水辺空間と緑地空間における魅力について春から秋にかけて 季節ごとに調査し, 各季節の魅力や印象の変化を明らかにするこ とを目的とした。都市における水と緑の空間は，人々に潤いや癒 しを感じさせ，多くの人の息いの場となっている。また，季節を 感じることは人々の生活や感性を豊かにさせる。季節の変化がは っきりしている日本において，この都市における水と緑の空間は 観光や健康など様々な面で重要な要素であり, より良い景観形成 には欠かせないものとなるであろう。

今回の研究調査では，鴨川の河川景観の印象の季節変化を把握 することができた。周辺環境の違う 2 区間で調査をした結果，魅 力を感じる要素や川全体に対する印象について各区間に共通する 傾向は，主に樹木や植物など自然に関する要素についてであり，
区間によって魅力や印象に違いが見られたのは, 街並みや川床な どの人工的な要素の有無によるものであった。来訪者にとって季 節を感じる空間づくりが重要だと思われていることが本研究のア ンケート結果から明らかになり, 季節变化する植物は重要な要素 であるが, それと同時に季節変化にあまり関与しない街並みが「京 都らしさ」という地域性を想起させる要因となっていた。空間整 備を行う上で自然的な要素と人工的な要素とのバランスを見極め ることで，地域性をもたせた季節変化を感じさせる親水空間の創 出が可能だと思われる。

アンケート調査をする中で, 中洲や雑草の管理の在り方, 生物 多様性を求める意見を聞いた。より良い景観を維持していく上で, 人の目線だけでなく多様な生物の目線での管理の仕方も課題とさ れる。この結果が，今後の良好な都市空間の創造につながること を期待したい。

\section{補注及び引用文献}

1 ) 㝨田辰彦・畔柳昭雄 (2005) : 東京都区部における親水公園整備の実態に関する調 查研究: ランドスケープ研究 68(5), 451-456

2 ) 国土交通省 (2003) : 美しい国づくり政策大綱 : 国土交通省, $12 \mathrm{pp}$

3 ) 国土交通省 : 景観緑三法: HP (http://www.mlit.go.jp/crd/townscape/keikan/, 2005 6.1更新, 2016.9.1参照

4 ) 石井一郎・元田良孝 (1990): 環境工学: 鹿島出版会, $228 \mathrm{pp}$

5 ) 国土交通省観光庁 (2015) : 観光立国実現に向けたアクション・プログラム 2015 : 国土交通省, 5-6

6 ) 京都府土木建設部 (2002) : 千年の都と鴨川治水 : 京都府京都土木事務所 $13 \mathrm{pp}$

7 ) 京都府:鴨川: HP 〈http://www.pref.kyoto.jp/kamogawa〉, 2016. 7. 10 更新, 2016. 9. 1 参照

8 ) 長聡子 (2013) : 河川空間構成と人の感性の関係に関寸る研究: 日本建築学会大会 学術講演梗概集 (北海道), 179-180

9 ) 松永翔吾・中嶋満彦・Didit Novianto・高偉俊 (2013) : 北九州市における川沿い の歩行空間の景観的役割とその有効性に関寸る研究: 日本建築学会研究報告 52 , 257-260

10）江頭正成・中西章敦・佐藤成治・小林祐司・姫野由香 (2014): 里川集落の河川景 観における心理評価一里川集落の空間特性および人と河川との関わり方 その 10 : 日本建築学会大会学術講演梗概集 (近畿)，277-278

11）武藤由香里・石田光男・下川海雄・池口仁・御園生拓・北村眞一 (2010) : 河川景 観の快適性に関する主観評価と行動指標による評価の比較: 景観・デザイン研究論 文集 $8,11-20$

12）杉虎之助・桜井愼一・大西淳 (2008) : 都市内狭小河川の週計・環境整備に関寸る 研究 その 2 : 日本建築学会大会学術講演梗概集 (中国)，385-386

13）増田昇・安部大就・下村泰彦・山本聡・加我宏之（1993）: 周辺環境を考慮した都 市河川空間整備モデルに関する研究 : 造園杂隹志 56(5)，223-228

14）渡辺敏・前野詩朗・馬場俊介 (2006) : 樹林化に伴う河川景観変化の土木史的考察 : 土木史研究論文集 $25,137-147$

15）中村良夫・北村眞一 (1988) : 河川景観の研究およひ設計：土木学会論文集 399, 13-26

16）浅川昭一郎・渡刃大介・首篫健一 (1994) : 多面性を有する緑地のイメージ構成に 関寸る事例研究: 造園䧱誌 57(5)，307-312

17）村川三郎・西名大作・安野淳 (1998) : スライド実験による地域景観の評価構造に 関寸る研究 その 2. 季節変化による検討: 日本建築学会中国支部研究報告集 21 , 385-388

18）福井亘・長島千紘 (2013) : 京都市白川周辺における来訪者の景観意識と快適空間 につい: ランドスケープ研究技術報告集 7，42-45

19）京都市 (2015) : 平成 26 年度京都観光総合調査 : 京都市産業観光局, 15-16

20) 京都市 (2016) : 平成 27 年度京都観光総合調查 : 京都市産業観光局, 15-16

21）宮岸幸正 (1999) : 京都市鴨川の水辺空間における経路パターンと魅力性 : 日本建 築学会近畿支部研究報告集 $39,581-584$

22) 京都府 (2010) : 鴨川河川整備計画 : 京都府, 25pp

23）今西純一・福井亘 (2015) : 緑・健康研究部会ワークショップ 2014 : 日本緑化工 学会誌 40(3), 510-511

24）高橋光幸 (2014) : 観光資源の定義と分類に関寸る考察 : 富山国際大学現代社会学 部紀要 $6,109-125$

25）岩本豊彦 (1983) : SD 法によるイメージ測定 : 川島書店，43-129

26) 福井亘 (2014) : バングラディッシュ・チッタゴンの都市部に住む若年層の景観涼 識調査について:ランドスケープ研究 77(5)，681-684

27）大塚芳嵩・岩崎宽 (2012) : 都市緑地における利用者の休憩場所に対寸る満足度・ 印象評価に関寸る研究: 日本緑化工学会誌 38(1), 127-129

28）向後个春・富永敦子 (2011)：統計学がわかる：技術評論社，118-161

29）涌井良幸・涌井貞美 (2014) : 多変量解析がわかる:技術評論社，97-136

30）解析ソフトは, SSRI社製エクセル統計 2012 を使用した。

31）福井亘・山本聡 (2010) : 囲繞景観における景観要素抽出の簡素化手法について: ランドスケープ研究 73(5)，559-562 